\title{
Corporate Social Responsibility Programs for Arctic Companies to Attract Young People
}

\author{
Marina N. KRUK \\ Ph.D. (Economics), Associate Professor \\ Associate Professor of the Department of organization and management \\ Faculty of Economics \\ Saint Petersburg Mining University \\ 2 21st Line Str., Saint Petersburg, 199106, Russia \\ Kruk_MN@pers.spmi.ru

\section{Anni Yu. NIKULINA} \\ Ph.D. (Economics) \\ Associate Professor of the Department of Organization and Management \\ Faculty of Economics \\ Saint Petersburg Mining University \\ 221 st Line Str., Saint Petersburg, 199106, Russia \\ Nikulina_AYu@pers.spmi.ru
}

\section{Vladislava D. SIMONCHUK}

Student of MP-17 group

Faculty of Economics

Saint Petersburg Mining University

221 st Line Str., Saint Petersburg, 199106, Russia

s170778@stud.spmi.ru

Presidential grant RSF No. 17-78-20145 "Socio-economic mechanism for attracting human resources to the Arctic region of the Russian Federation"

\begin{abstract}
The article presents the results of a study of corporate social responsibility (CSR) programs of the largest mining companies in Russia, Canada, Finland, and Norway operating in regions with unfavorable climatic conditions. A comparative assessment of CSR programs showed that Canadian companies are leading in such areas as "Rewards and motivation", "Labor protection", and "Investment in environmental measures". Russian companies place more emphasis on
\end{abstract}


implementing sponsorship and charity programs externally, and on training, developing and adapting their staff internally. Russian companies - OJSC "Severstal", OJSC "MMC "Norilsk Nickel", and OJSC PhosAgro - take the second place in terms of total points. In particular, PhosAgro has the largest number of CSR activities.

Keywords: Arctic; Far North; corporate social responsibility; mining companies; human resources.

\section{Introduction}

The Russian Arctic is a huge territory of new opportunities, including the mining industry, but there is currently a problem of attracting human capital to the North due to difficult working conditions.

Today all the Arctic territories of the Russian Federation are experiencing a constant outflow of population, primarily young people of working age. Young people often go to big cities for higher education and "settle" in them, believing that employment in their hometown is impossible. Young people not from Northern cities are not ready to go to work in the Far North or in the Arctic due to natural and climatic factors, as well as sometimes due to insufficient awareness of employment opportunities and career growth (Sharok, 2018; Ivanovaб Zaycev, 2016; Ivanova et al., 2017; Cherepovitsyn, 2015).

Thus, the study is generally aimed at determining the factors that qualified professionals expect from work in the North, as well as the conditions that mining companies can offer them.

This article analyzes the corporate social responsibility programs of the largest Russian mining companies operating in the Arctic, their comparison with foreign companies, as well as a qualitative and quantitative assessment of such programs.

Several major mining companies operating in the Arctic zone or in areas with unfavorable climatic conditions, with available corporate social responsibility (CSR) reporting, were identified as the object of research: Russian companies included in the Forbes list as the best employers (Forbes Rating. 50 best employers in Russia, 2019) - OJSC "MMC "Norilsk Nickel" (nonferrous metals), OJSC "Severstal" (metallurgy), OJSC "PhosAgro" (phosphoric fertilizers) and foreign companies ImperialOil (oil mining) - Canada, RioTinto (bauxite mining and alumina, aluminum plants) multinational company (production in Canada and Mongolia); Nordkalk (mining, processing of limestone) - Finland; Equinor (oil and gas production) - Norway; Nordic mining (geological exploration, production of titanium, quartz and lithium) - Norway.

\section{Methods}

To select the research method, existing domestic and foreign literature sources were analyzed (Cravero, 2017; Gamu, Dauvergne, 2018; Hurst, Ihlen, 2018, pp. 133-152; Kelman et al., 2016; Poussenkova et al., 2016; Sahut, 2019; Witt, Miska, 2019, pp. 605-619; Leshchenko, Korchagina, 2016). In order to conduct a qualitative analysis of CSR programs of mining companies, the system of diagnostics of internal and external directions of corporate and social programs development, developed by Dambovskaya (2015), was adopted. Diagnostics consists in determining the satisfaction of the company's personnel in the activities carried out within the framework of CSR programs. The authors used this diagnostics for comparative analysis, as well as to identify opportunities for improving CSR programs of the analyzed companies. The directions of diagnostics (internal and external) are defined, and within these directions the characteristics for which the assessment is given are highlighted. When diagnosing the internal direction of corporate social policy, such indicators as "Rewards and motivation", "Professional training, development and adaptation of personnel", "Labor protection", "Social programs, social infrastructure" were used. To diagnose the external directions of CSR programs, assessments are given using the following characteristics: "Implementation of charitable programs", "Implementation of sponsorship 
programs", "Development of the region's infrastructure", "Investments in environmental protection measures". Figure 1 shows the indicators that were analyzed.

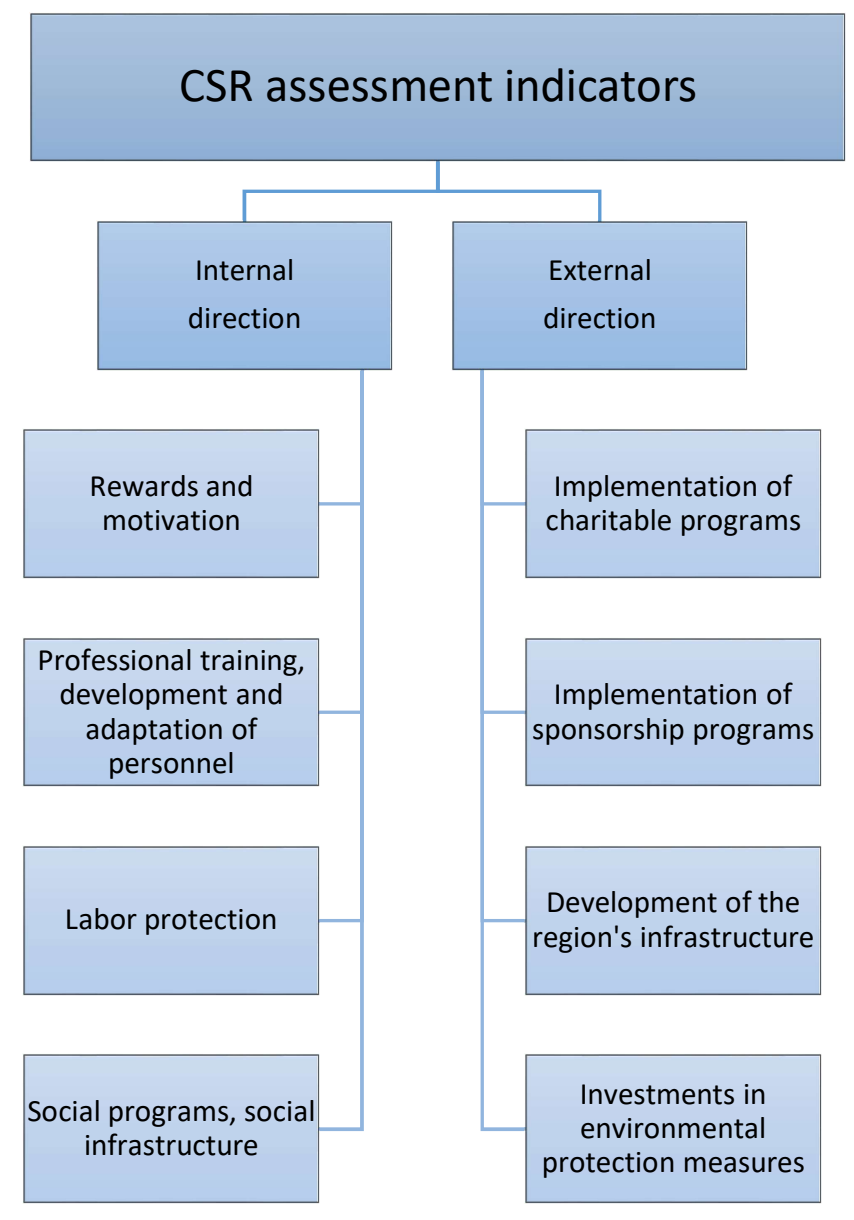

Figure 1. Characteristics of CSR program evaluation

\section{Results}

Based on the presented methodology, a comparative analysis of corporate social responsibility programs of Russian and foreign companies is performed. The results are presented as an information map (Table 1). 
Table 1. Information map of corporate social policy of the analyzed companies (Kruk, 2018; Nikulina et al., 2018, 2019; Kotlyar, 2018; Simonchuk, 2018; Feoktistova et al., 2018)

\begin{tabular}{|c|c|c|c|c|}
\hline & Indicators & $\begin{array}{l}\text { Canadian companies } \\
\text { (ImperialOil, RioTinto) }\end{array}$ & $\begin{array}{c}\text { Scandinavian companies } \\
\text { (Nordkalk, Equinor, Nordic mining) }\end{array}$ & $\begin{array}{l}\text { Russian companies } \\
\text { (OJSC "MMC "Norilsk Nickel", OJSC "Severstal”, } \\
\text { OJSC "PhosAgro" }\end{array}$ \\
\hline & Rewards and motivation & $\begin{array}{l}\text { 1. Average salary of about } 100 \\
\text { thousand US dollars per year - Imperial } \\
\text { Oil; } \\
\text { 2. Attracting personnel from other } \\
\text { countries (a number of such programs - } \\
\text { the provincial program of Alberta, } \\
\text { British Columbia, Manitoba-Imperial } \\
\text { Oil); } \\
\text { 3. Providing staff with comfortable } \\
\text { housing, living and working conditions. }\end{array}$ & $\begin{array}{l}\text { 1. The average salary of about } 108 \text { thousand } \\
\text { US dollars Norwegian company Equinor. } \\
\text { 2. Attracting staff living in the Baltic and } \\
\text { Scandinavian countries (Nordkalk). } \\
\text { 3. Providing staff with comfortable housing, living } \\
\text { and working conditions. }\end{array}$ & $\begin{array}{l}\text { 1. The average salary is } 94.2 \text { and } 64.69 \text { thousand } \\
\text { rubles in MMC Norilsk Nickel and Severstal (which } \\
\text { is } 1,474 \text { US dollars). } \\
\text { 2. At "Severstal", the system of incentives and } \\
\text { bonuses for employees is documented. } \\
\text { 3. Application of a progressive approach in the } \\
\text { system of rewards of personnel based on grades in } \\
\text { MMC "Norilsk Nickel". }\end{array}$ \\
\hline 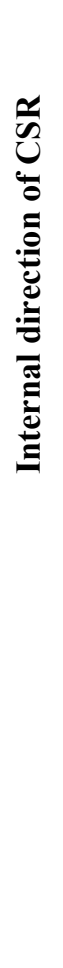 & $\begin{array}{l}\text { Professional training, } \\
\text { development and } \\
\text { adaptation of personnel }\end{array}$ & $\begin{array}{l}\text { 1. Recruitment of staff with little } \\
\text { experience (Alberta students have the } \\
\text { opportunity to get a job at Imperial Oil } \\
\text { after university). } \\
\text { 2. Conducting training programs (local } \\
\text { colleges, Northern Alberta Institute, } \\
\text { Edmonton Institute of Technology- } \\
\text { Imperial Oil). }\end{array}$ & $\begin{array}{l}\text { 1. Nordkalk cooperates with a number of schools } \\
\text { and universities, attracting young professionals to } \\
\text { work in their company (scholarship program, } \\
\text { organization of international seminars). } \\
\text { 2. Conducting career fairs to attract young } \\
\text { professionals - Equinor. }\end{array}$ & $\begin{array}{l}\text { 1. The provision of social packages for employees. } \\
\text { 2. Continuous training throughout the entire working } \\
\text { life (corporate training centers in Norilsk, } \\
\text { Monchegorsk) - MMC "Norilsk Nickel". } \\
\text { 3. Program for adaptation and development of new } \\
\text { employees. } \\
\text { 4. Development and implementation of projects for } \\
\text { children and youth - Initiator of projects in } \\
\text { "PhosAgro-School", "PhosAgro-College". } \\
\text { (PhosAgro). More than } 10 \text { school children took part } \\
\text { in this program. } \\
\text { 5. Organizer and active participant of the Center for } \\
\text { International competence in mining and technical } \\
\text { education (PhosAgro) - } 6,447 \text { completed man- } \\
\text { courses. } \\
\text { 6. Initiator and sponsor of the joint grant program for } \\
\text { young scientists in the field of chemistry (PhosAgro) } \\
\text { with UNESCO and IUPAC - } 48 \text { young specialists } \\
\text { were accepted to PhosAgro. } \\
\text { 7. Participant of the joint program with the Ministry } \\
\text { of agriculture of the Russian Federation and the Food } \\
\text { and agriculture organization of the United Nations to } \\
\text { train farmers in more effective solutions in the field } \\
\text { of sustainable agriculture (especially in the field of }\end{array}$ \\
\hline
\end{tabular}


soil fertility) (PhosAgro).

8. Conducting a training on the strategic

development of JSC "Metahim" for employees -

PhosAgro.

9. Cooperation with higher educational institutions to attract qualified specialists to work:

- financing of training of PhosAgro - class graduates in profile specialties, subject to signing a contract for further employment;

- providing scholarships to the most outstanding students (based on exam results);

- inviting university students to take a tour in one of the company's enterprises, allowing them to see the technology in action;

- inviting university graduates to join the company in one of the most popular specialization programs

"Young talented employee»

1. The workplace is certified. Training of 1 . The workplace is certified. Training of personnel personnel on labor protection issues in the organization is provided and is of a regular nature (Imperial Oil, Rio Tinto). 2. The company ensures high safety of on labor protection issues in the organization is provided and is of a regular nature.

Labor protection

Social programs, social infrastructure

\section{personnel (the company's injury rate is 0 - title "Zero injuries").}

Imperial Oil).

1. Attracting local people to work at Rio Tinto.

2. Providing comfortable housing for employees (more than 200 Rio Tinto employees live in new houses, and rents are returned to the local economy, which guarantees independence for local communities)

3. Pension programs (Imperial Oil invested about $\$ 3.2$ million in employee pensions)
1. Health care program for employees (Nordkalk collaboration with the medical company

"Terveystalo", which provides medical services)

2. Increasing the level of employment of the local population (Terveystalo has about 4,300 employees since the arrival of Nordkalk).

3. Equinox provides high-quality medical care for its employees.

1. The workplace is certified. Training of personnel on labor protection issues in the organization is provided and is of a regular nature - Severstal, PhosAgro, MMC Norilsk Nickel.

Development of the labor safety system in Severstal: in 2018, the Company allocated 4.4 billion rubles for measures in the field of labor safety and industrial safety.

1. Provision of vouchers to health resorts (holiday in the sanatorium "Zapolyarye", which is on the balance sheet of MMC "Norilsk Nickel").

2. Treatment and leisure time for employees in the sanatorium "Tirvas".

3. Its own healthcare program for employees of the company Severstal Health.

4. Support for sports, mini-football, volleyball,

hockey, etc., as well as family sports ("polar

Olympics") - MMC "Norilsk Nickel".

5. Housing programs for employees ("Our homes",

"My home") - MMC "Norilsk Nickel".

6. Pension provision program and support program

for pensioners - "Severstal",

7. Assistance to regional and local authorities in 
creating modern social infrastructure (PhosAgro).

8. Agreement on the promotion of cooperation and implementation of projects aimed at increasing the social attractiveness and socio-economic

development of the region, between OJSC PhosAgro and the administration of the Saratov region PhosAgro.

9. Agreement on cooperation and assistance between the Government of the Vologda region, OJSC

"PhosAgro" and JSC "Apatit" - PhosAgro.

10. More than 1.5 billion rubles were allocated to social support and charity-PhosAgro.

1. Support of the local population of Mongolia and Australia - Rio Tinto. 2. Sponsorship programs.

Implementation of charitable programs

Uี

Implementation of sponsorship programs
1. Cooperation with educational organizations, conducting specialized programs (local colleges and Technology in Edmonton).

2. Career fairs with an aim to attract young specialists (Imperial Oil, Rio Tinto).
Nordkalk company invested 1 million Euros to build the children's hospital in Helsinki.
1. Support and development of sports, holding regional sports events (Nordkalk was one of the of sponsors of the Yukol relay, organized in Lappeenranta in Finland).

2. Cooperation with educational institutions, conducting specialized programs (Equinor program for 30 newly formed candidates-provides free training for 1 year for young professionals).

3. Conducting career fairs to attract young professionals - Equinor.
1. Relocation program-MMC "Norilsk Nickel". 2. Support of the local population of the North MMC "Norilsk Nickel".

3. "The world of kind opportunities" program (the development of social competencies of the local community representatives, implementation of the new social technologies) - MMC "Norilsk Nickel". 4. Support and stimulation of the public initiatives, conditions development for the intersectional partnership).

5. Charitable programs to prevent child abandonment, support social organizations, NPO, social initiative communities -"Severstal".

6. Help and support children with disabilities "Severstal".

1. Sponsorship of the Rosa Khutor mountain resort MMC "Norilsk Nickel".

2. Assistance in the implementation of Olympic educational programs of the Russian international Olympic University - MMC "Norilsk Nickel".

. Support of the international student sports

federation - MMC "Norilsk Nickel".

4. Support for the basketball club CSKA - MMC

"Norilsk Nickel".

5. Support of the mini-football club "Norilsk Nickel" - MMC "Norilsk Nickel".

6. Assistance in holding the XXIX world winter Universiade in Krasnoyarsk - MMC "Norilsk 
Development of the region's infrastructure
1. Participation in the development of infrastructure in the region is regular, o their own initiative (Rio Tinto).

2. Infrastructure development (Rio T

in Mongolia invested in programs to

support the Mongolian population,

workers' wages more than 5.4 billion US

dollars in the period from 2010 to 2015 )
1. Support programs for small and medium-sized businesses, development of social entrepreneurship in the regions of presence (Nordic mining uses local suppliers).

\section{Nickel"'}

7. Support and development of sport activities, carrying out regional sports events - "Severstal". 8. The youth movement "Education, Health and Spirituality for Children of Russia" (DROZD) has opened a children's sports and wellness center in Balakovo - PhosAgro.

9. 34 grants were issued to young scientists from 26 countries in Asia, Africa, the Middle East, Europe and Latin America - PhosAgro.

10. Holding of the workers' sports contest -

"PhosAgro".

1. Agreement with regional authorities and a number of municipalities on cooperation in the socioeconomic sphere - "Severstal".

2. Participation in the development of the region's infrastructure is regular, on their own initiative, within the funds provided by the social budget MMC "Norilsk Nickel".

3. Programs to support small and medium - sized businesses, development of social entrepreneurship in the regions where "Severstal" operates.

4. Ensuring economic prospects for local suppliers and stimulating the development of local partners PhosAgro.

1. Measures to reduce harmful emissions 1. Efficient use of natural resources (Nordkalk is to the atmosphere (Rio Tinto has reduced committed to $100 \%$ efficient use of materials). gas production by 27 since $2008 \%$ ). $\quad 2$. Use of biofuels (Nordkalk).

Investments in 2. Use of renewable, environmentally

3. Construction of a sound bartien

. measures company's electricity)

4. Providing residua 3. Activities aimed at cleaning up (Nordkalk). reservoirs (Rio Tinto).

1. Environmental management system. In 2018, the cost of environmental protection amounted to 32.5 billion rubles $(+26.5 \%$ by 2016$)-\mathrm{MMC}$ "Norilsk Nickel".

2. Energy saving and energy efficiency improvement program for 2015-2019 at Cherepovets metal processing plant - "Severstal".

3. The company's environmental management complies with ISO standards - "Severstal", MMC "Norilsk Nickel".

4. Reducing waste, emissions and discharges of pollutants, as well as consumption of resources per ton of manufactured products due to investment in new, more efficient technologies - in 2018 , Metakhim JSC (Volkhov) introduced a drainless 
production system, as a result, the discharge of wast water into water bodies (PhosAgro) was stopped.

5. Over 5 years PhosAgro has spent 7.6 billion rubles on environmental protection.

6. Reducing emissions by $6 \%$ in 2018 due to the

introduction of new eco-friendly equipment, as well

as improving environmental management systems -

"PhosAgro".

7. The principle of using approaches to preserve

biodiversity: freshwater ecosystems, spawning rivers - construction of treatment facilities and measures to

replenish biological resources, conservation of

animal migration routes - "PhosAgro".

8. PhosAgro became the first Russian company

selected by the Food and agriculture organization of

the United Nations (FAO) to implement the global

soil protection initiative. 
Companies were evaluated by experts. For this purpose, scientists from the Saint Petersburg Mining University - specialists in the field of organization and management, sociology and psychology were involved as an evaluation jury. Based on the analysis of the information map, companies were awarded points (from 1 to 10 ) for each evaluation criteria, the maximum value of 10 points was given to the companies that did the most work in the evaluated area. Experts 'assessment of companies' performance by points is shown in Table 2 .

\section{Table 2. Results of comparative assessment of CSR of Arctic companies}

\begin{tabular}{|c|c|c|c|}
\hline \multicolumn{4}{|c|}{ Internal direction of CSR activities } \\
\hline & $\begin{array}{l}\text { Canadian } \\
\text { companies }\end{array}$ & $\begin{array}{c}\text { Scandinavian } \\
\text { companies }\end{array}$ & Russian companies \\
\hline Rewards and motivation & 9 & 10 & 5 \\
\hline $\begin{array}{l}\text { Professional training, } \\
\text { development and } \\
\text { adaptation of personnel }\end{array}$ & 7 & 6 & 10 \\
\hline Labor protection & 10 & 10 & 7 \\
\hline Social programs & 9 & 7 & 8 \\
\hline \multicolumn{4}{|c|}{ External direction of CSR activities } \\
\hline & $\begin{array}{l}\text { Canadian } \\
\text { companies }\end{array}$ & $\begin{array}{c}\text { Scandinavian } \\
\text { companies }\end{array}$ & Russian companies \\
\hline $\begin{array}{l}\text { Implementation of } \\
\text { charitable programs }\end{array}$ & 7 & 4 & 9 \\
\hline $\begin{array}{l}\text { Implementation of } \\
\text { sponsorship programs }\end{array}$ & 7 & 7 & 9 \\
\hline $\begin{array}{l}\text { Implementation of } \\
\text { sponsorship programs }\end{array}$ & 8 & 4 & 6 \\
\hline $\begin{array}{l}\text { Investments in } \\
\text { environmental protection } \\
\text { measures }\end{array}$ & 7 & 9 & 5 \\
\hline Total score & 64 & 57 & 59 \\
\hline
\end{tabular}

Figures 2 and 3 show the results of CSR assessment of companies in internal and external areas of activity. The graphical representation allows you to evaluate the effectiveness of corporate social programs for each of the areas. 
* Canadian companies _ - Scandinavian companies

- Russian companies

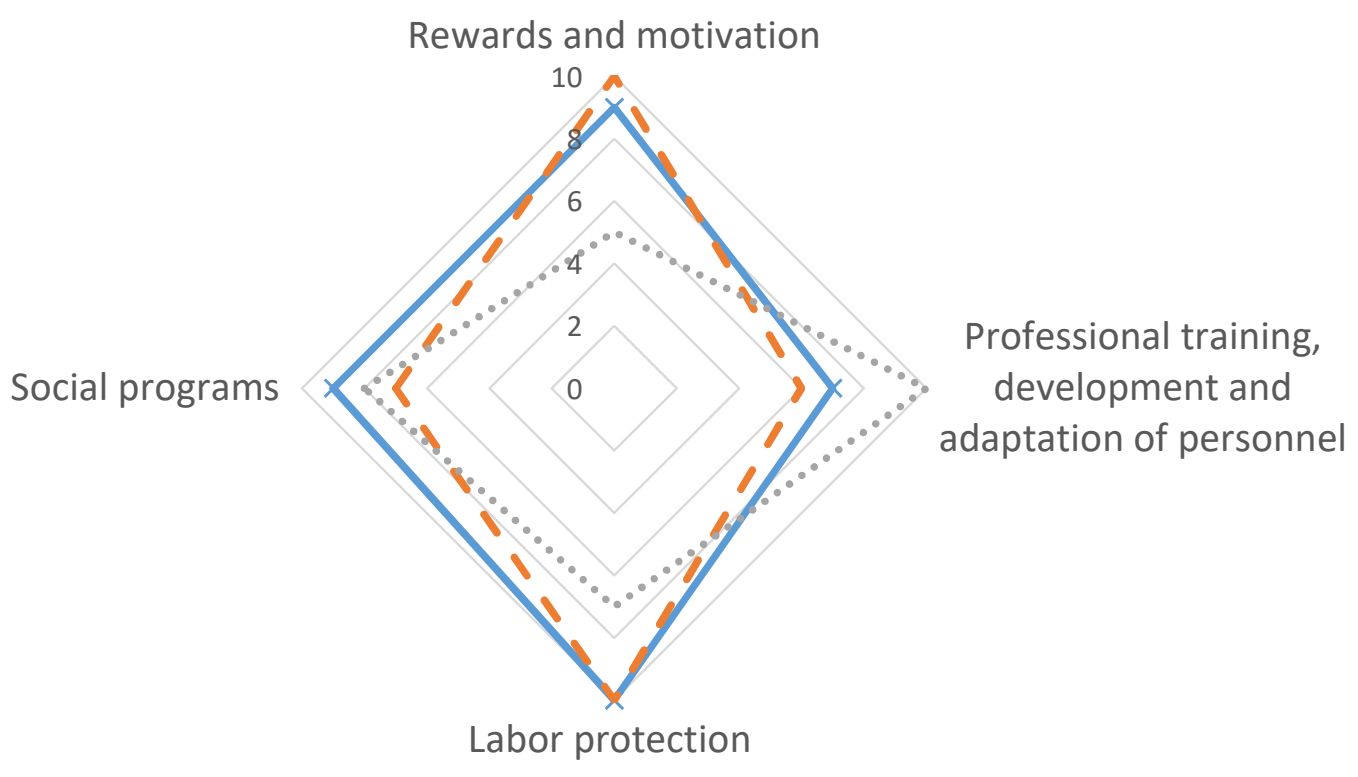

Figure 2. Internal direction of CSR activities of companies

Canadian companies - - Scandinavian companies..... Russian companies

Implementation of

charitable programs

10

Investments in

environmental

protection measures

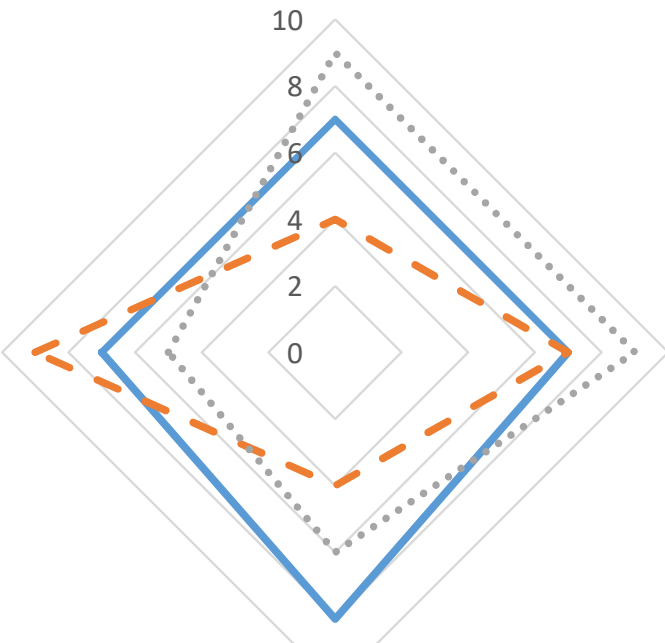

Implementation of sponsorship programs

Implementation of

sponsorship programs

Figure 3. External activities within the framework of CSR of companies 
In terms of total points, the Canadian companies ImperialOil and RioTinto were the leaders, with a total score of 64 points for their CSR programs (table 2). Canadian companies are leading in the areas of "Rewards and motivation", "Labor protection", and "Investment in environmental measures" in the external evaluation area.

The second place in total points (59) is taken by Russian companies - OJSC "Severstal", OJSC "MMC "Norilsk Nickel", and OJSC "PhosAgro". In particular, PhosAgro has the largest number of events. Russian companies place more emphasis on implementing sponsorship and charity programs externally, and on training, developing and adapting their staff internally.

The third place is taken by Scandinavian companies-Nordkalk, Equinor, and Nordic mining (57 points). In their activities, they pay more attention to environmental measures, which are often innovative in nature. Also, Finnish and Norwegian companies implement many sponsorship programs, have a higher number of points in the direction of "Rewards and motivation of personnel", and also take care of their staff, having the highest rating in the direction of "Labor protection".

\section{Discussion}

Some CSR indicators are quantitative (for example, the level of wages, the percentage of investments in environmental activities), and some are qualitative (staff development and adaptation), so the results of the assessment are subjective. However, such results can be used by companies to adjust the direction of their CSR programs, as well as by potential employees to choose the best employer. The choice of analyzed enterprises, both foreign and domestic, is also a debatable issue.

\section{Conclusion}

Thus, we can conclude that Canadian, Scandinavian, and Russian companies carry out effective activities within the framework of CSR. However, a comparative analysis showed that Canadian companies Imperial Oil and Rio Tinto outperform Scandinavian and Russian companies. Speaking about improving the activities of foreign companies, we can advise to improve the activities in the direction of "Professional training, development and adaptation of personnel", as well as "Implementation of sponsorship and charity programs".

Speaking about improving the activities of domestic companies, it is worth paying attention to the direction of "Rewards and motivation of personnel", "Investment in environmental protection measures", "Development of regional infrastructure", since attracting labor resources to the Arctic regions requires the creation of a full-fledged infrastructure suitable for human life and cultural and everyday objects.

Comparing foreign and domestic companies, we can conclude that European and Canadian companies, unlike Russian ones, have more transparency and accuracy in CSR indicators.

\section{Funding}

The research was carried out at the expense of a grant from the Russian science Foundation (project № 17-78-20145 "Socio-economic mechanism for attracting human resources to the Arctic region of the Russian Federation") at the Saint Petersburg Mining University.

\section{References}

Cherepovitsyn, A.E. (2015). Socio-economic Potential of large-scale projects for the development of the oil and gas shelf: risks and expectations of interested parties. Journal of Mining 
III International Theoretical and Practical Conference "The Crossroads of the North and the East (Methodologies and Practices of Regional Development)"

Institute, $\quad 215, \quad 140 . \quad$ (in $\quad$ Russian). $\quad$ Retrieved from http://pmi.spmi.ru/index.php/pmi/article/view/5193

Cravero, C. (2017). Socially Responsible Public Procurement and Set-Asides: A Comparative Analysis of the US, Canada and the EU. Arctic Review, 8. https://doi.org/10.23865/arctic.v8.739

Dambovskaya, A.A. (2015). Diagnostics methods of internal and external directions of corporate social policy development. Russian entrepreneurship, 16(13), 2035-2044. (in Russian) https://doi.org/10.18334/rp.16.13.487

Feoktistova, E.N. (2018). Russian business and sustainable development goals: corporate collection of practices. M.: RSPP. (in Russian)

Forbes Rating. 50 best employers in Russia. (in Russian). (2019). Retrieved from https://www.forbes.ru/rating/387403-50-luchshih-rabotodateley-rossii-2019

Gamu, J.K., Dauvergne, P. (2018). The slow violence of corporate social responsibility: The case of mining in Peru. Third World Quarterly, 39(5), 959-975. https://doi.org/10.1080/01436597.2018.1432349

Hurst, B., Ihlen, Ø. (2018). Corporate social responsibility and engagement. (K. A. Johnston \& M. Taylor, Eds.), Handbook of communication engagement. Malden, MA: Wiley-Blackwell.

Ivanova, M.V., Zaycev, D.V. (2016). Arctic workforce: current state and future challenges. Regional economics: theory and practice, 14(10), 46-62. (in Russian)

Ivanova, M.V., Balevski, T.V., Zaitsev, D.V. (2017). Arctic labor market. Problems of territorial development, (1), 145-157. (in Russian)

Kelman, I. (2016). Local Perceptions of Corporate Social Responsibility for Arctic Petroleum in the Barents Region. Arctic Review, 7(2). https://doi.org/10.17585/arctic.v7.418

Kotlyar, B.A. (2018). Organization of production and payment of labor: dependence and influence. Non-ferrous Metals, 4, 8-18. (in Russian)

Kruk, M. (2018). Opportunities for improving the corporate social responsibility programs for metallurgical companies in the Arctic. Non-ferrous Metals, 44(1), 3-6.

Leshchenko, O.A., Korchagina, E.V. (2016). Modern methods of evaluating the effectiveness of companies in the field of CSR. Management in Russia and abroad, 1, 11-18. (in Russian)

Nikulina, A. (2018). Factors for mobilizing human resources to work in the Arctic. Arctic: History and Modernity: works of the Annual International Scientific Conference, St. Petersburg, 1819 April, 2018, 90-97. https://doi.org/10.18720/SPBPU/2/id19-124

Nikulina, A., Simonchuk, V., Sharanovskaya, P. (2019). Experience of Canadian companies in attracting human capital to regions with severe climatic conditions. Arctic: History and Modernity: works of the Annual International Scientific Conference, St. Petersburg, 18-19 April, 2018, 104-111. https://doi.org/10.18720/SPBPU/2/id19-126

Poussenkova, N. (2016). Corporate Social Responsibility. Russian Analytical Digest, 81. Retrieved from https://css.ethz.ch/en/services/digital-library/publications/publication.html/196541

Sahut, J.M. (2019). Corporate social responsibility and governance. In. Journal of Management and Governance, 23(4), 901-912. https://doi.org/10.1007/s10997-019-09472-2 
Sharok, V. (2018). Communicative factors of socio-psychological adaptation of students and workers in the Arctic. The European Proceedings of Social \&Behavioural Sciences, 51, 1776-1786. https://doi.org/10.15405/epsbs.2018.12.02.189

Simonchuk, V.D. (2018). Experience of the Scandinavian countries in creating effective corporate social responsibility programs. Collection of scientific work II Russian student scientific practical conference (2018, December 28), 473-476 (in Russian)

Witt, M.A., Miska, C. (2019). Institutions and Corporate Social Responsibility. In Abagail McWilliams, Deborah Rupp, Donald Siegel, Günter K. Stahl, \& David Waldman (Eds.), The Oxford Handbook of Corporate Social Responsibility: Psychological and Organizational Perspectives. Oxford, UK: Oxford University Press. http://dx.doi.org/10.2139/ssrn.3160023 